\title{
Tujuan Pemidanaan dan Pertimbangan Hakim dalam Menjatuhkan Pidana Terhadap Pengguna Sekaligus Pengedar Narkotika
}

\author{
Nabain Yakin \\ Fakultas Hukum, Universitas Muhammadiyah Yogyakarta \\ Email : nabain.yakin.2014@law.umy.ac.id
}

\begin{abstract}
Info Artikel
Kata Kunci :

Pemidanaan,

Tindak Pidana Narkotika,

Penegakan Hukum

Perjalanan Artikel :

Diterima : 17 Januari 2020

Direview : 01 Februari 2020

Direvisi : 12 Maret 2020

Dipublikasikan : Maret 2020

DOI: 10.18196/ijclc.v1i1.9103

Abstrak

Narkotika adalah masalah terbesar di negara Indonesia. Bisa dikatakan narkotika adalah musuh bersama. Penyalahgunaan narkotika di Indonesia semakin hari semakin meluas, tentu ini sangatlah mempengaruhi dan merusak generasi muda. Penegak hukum dan seluruh elemen masyarakat harus bersatu untuk memerangi masalah narkotika ini, karena kita tau bahwa dampak negative dari pemakaian narkotika ini sangat dahsyat, bukan hanya diri sendiri melainkan bangsa dan negara. Penegakan hukum terhadap pengguna sekaligus pengedar narkotika haruslah seberat mungkin, agar diharapkan bisa menekan maraknya penggunaan narkotika di masyarakat Indonesia, khususnya generasi muda. Jenis penelitian yang penulis gunakan adalah penelitian hukum normatif, bahan-bahan yang dapat dijadikan objek dalam penelitian normatif adalah bahan-bahan yang berupa primer, bahan sekunder, dan tersier. Penelitian yang penulis lakukan juga menggunakan system wawancara atau tanya jawab dengan Hakim Pengadilan Negeri Yogyakarta untuk mengumpulkan segala informasi tentang penelitian yang ditulis peneliti. Hasil penelitian yaitu Penjatuhan Sanksi Pidana terhadap Pelaku Pengguna sekaligus Pengedar Narkotika dalam perkara penyalahgunaan narkotika dengan Pertimbangan Hakim dalam Pemidanaan terhadap Pengguna sekaligus Pengedar Narkotika, tentunya dengan pertimbangan pedoman Perundang-Undangan Narkotika dan pertimbangan dakwaan yang di ajukan oleh jaksa penuntut umum. Narkotika saat ini sudah sangat meresahkan masyarakat Indonesia karena benda ini adalah benda yang apabila di konsumsi oleh penggunanya akan berdampak buruk.
\end{abstract}

\section{Pendahuluan}

Indonesia adalah satu di antantara negara-negara lain yang tengah berkembang, dan rentan terhadap sasaran potensial untuk memproduksi dan pengedaran obat-obatan terlarang seperti narkotika secara melawan hukum atau ilegal. Negara seperti Indonesia menjadi sarana untuk dijadikan tempat perlintasan narkotika, oleh karena itu kejahatan narkotika ini bukan lagi kejahatan yang sifatnya bersakala kecil, tetapi telah menjadi permasalahn seluruh elemen bangsa dan nasional, yang juga sering dijadikan sebagai tempat transit bagi para pelaku sebelum mereka sampai ketempat tujuan di negara lain. Oleh karena itu data perkembangan kasus pidana narkotika ini semakin mengalami peningkatan dari tahun ke tahun.

Narkotika bisa diibaratkan seperti parang bermata dua yang tajam, disuatu sisi bisa digunakan didalam dunia medis atau dunia ilmu pengetahuan, akan tetapi disatu sisi penyalahgunaan narkotika ini tentu sangat berbahaya bagi masa depan generasi muda, dan juga akan mengancam eksisnya pengetahuan nasional sebuah bangsa dan negara, hingga dibutuhknnya suatu aturan hukum yang 
mengatur pernyalahguanaan narkotika sehingga diharapkan bias menekan banyaknya jumlah penyalahgunaan atau peredaran narkotika ini. Adanya peran warga negara asing dalam perdagangan gelap narkotika di Indonesia menjadi indikasi bahwa kejahatan ini telah dilakukan secara terorganisir dengan baik yang melibatkan jaringan Internasional dan menciptakan Indonesia sebagai salah satu pasar besar untuk melakukan peredaran narkotika. ${ }^{1}$

Pada era sekarang ini penyalahgunaan narkotika sudah sampai tingkat mengkhawatirkan. Pada saat ini Indonesia sedang mengalami darurat narkotika, dilihat dari hasil penelitian Badan Narkotika Nasional (BNN) yang bekerjasama dengan Pusat Penelitian Kesehatan Universitas Indonesia Tahun 2014 tentang survey Nasional perkembangan penyalahgunaan Narkotika di Indonesia, yang didapat angka penyalahguna narkotika adalah sebanyak $2,18 \%$ atau sekitar 3,8 juta orang pernah pakai narkotika dalam kurun waktu setahun terakhir pada usia 10-59 tahun. ${ }^{2}$

Meluasnya peredaran narkotika mesti diawasi dengan ketat oleh penegak hukum yang terkait agar tidak beredar luas di generasi milenial. Karena seperti yang kita tahu bahwa manfaat dari narkotika sangatlah buruk dan biasa dipakai untuk hal yang negative. Disisi lain, semakin berkembangnya ilmu teknologi dan informasi dan komunikasi, bias menjadi alat untuk menyebarkan ke daerah wilayah Indonesia, seperti wilayah yang tadinya belum pernah tersentuh oleh narkotika semakin lama akan terjangkau juga oleh peredaran narkotika, bahkan bias jadi tempat sentral untuk peredarannya. Penyalahgunaan narkotika di berbagai kota besar Indonesia, ternyata mempunya cara lain yang dapat menyerang generasi milenial atau generasi muda. Hal tersebut tentu sesuatu yang sangat meresahkan dan merisaukan, karena mereka generasi milenial adalah generasi harapan seluruh rakyat Indonesia dan Bangsa dan negara untuk meneruskan kelangsungan kedaulatan bangsa secara dihormati. Efek yang diakibatkan oleh penyalahgunaan narkotika ini sangat dirasakan besar pengaruhnya pada pribadi maupun masyarakat. ${ }^{3}$

Bahaya dan ancaman dari peredaran narkotika ini adalah ancaman secara nasional yeng semestinya diatasi secepat dan sesegera mungkin, karena jika tidak disegerakan, efeknya memberikan ancaman yang serius bagi peradaban hidup manusia yang akhirnya dapat mengancam stabilitasisai nasional serta membahayakan pertahanan dan keamanan bangsa dan negara. Bahaya peredaran dan penyalahgunaan narkotika juga dapat menjadi pedang tajam yang menghunus keberlangsungan negara, dan menghambat pembangunan terlebih sumber daya manusinya, oleh karena itu dirasa sangat perlu diberantas oleh penegak hukum dan jajaran masyarakat.

Penerapan hukum terhadap kejahatan tindak pidana di Indonesia, yakin pemidanaan haruslah merujuk keapada pendekatan hukum bersifat memelihara para penjahat dengan cara pembinaan di penjara atau lembaga pemasuarakatan (LP), oleh karenanya bisa memperbaiki hidup siterpidana di penjara tersebut. Diharapkan hal seperti diatas hendaknya mampu memberikan pertimbangan kepada para hakim pengadilan untuk penjatuhan vonis pidana terhadap pelaku kejahatan supaya bisa merangkul aspirasi demi keadilan masyarakat. Mekanisme peredaran dan pemasaran narkotika sangat terakuisisi dengan adanya tempat hiburan malam dan pemasaran narkotika seringkali beredar di tempat hiburan tersebut. Terdapat suatu dilemma, dimana tempat hiburan memberikan lapangan pekerjaan dan pendapatan bagi daerah, dan juga menunjang perkembangan daerah tersebut. Akan tetapi disis lain tentunya memberi dampak yang sangat negatif, termasuk peredaran narkotika didalamnya. Hal-hal seperti ini disebabkan ketidakpatuhannya pengelola tempat hiburan dan tidak ikut bertanggung jawab atas apa yang terjadi jika ada peredaran dan penyalahguaan narkotika. Ada beberapa komitmen yang di setujui oleh para pengelola tempat hiburan, seolah-olah komitmen tersebut hanya untuk kepentingan perizinan saja, pada nyatanya banyak juga yang menjadi sumber pendapatan.

Pengakan hukum terhadap penyalahgunaan narkotika harusloah dicermati bagaimana penerapan sanksim atau pemidanaannya. Hukuman dalam bentuk ancaman dan bentuk harapan.

1 Aktualita, Menanggulangi tindak pidana narkotika dihubungkan dengan tujuan pemidanaan, Aktualita, Volume 1 Nomor 1, 2018,

2 Wawasan Yuriduka, penegakan hukum terhadap tindak pidana narkotika new psychoactive subtances berdasarkan undang-undang nomor 35 tahun 2009, 2017, Jurnal Volume 1 Nomor 1.

3 Andri Winjaya Laksana, Tinjauan Hukum Pemidanaan Terhadap Pelaku Penyalahguna Narkotika Dengan Sistem Rehabilitasi, Jurnal Hukum, 2015,Volume 2 Nomor 1. 
Penerapan hukum itu akan menimbulkan sebuah ancaman pada pelaku yaitu sanksi sifatnya alami, hingga menyadari kesalahan dan dapat menerima hukuman yang dijatuhkan. Karenanya dirasa sangat perlu kita mengembangkan suatu system pemidanaan dan memberi ganti yang setara. Untuk para pelaku tentu harus diberikan tindakan secara tegas didasari hukum dan norma yang berlaku. Factor-faktor dalam menentukan apakah senksi pidana yang diterapkan tepat atau tidak dalam penegakan hukumnya, apabila secara cepat dan tepat kasus sekecil apapun hukuman itu ditegakkan, maka tidak akan membesar dan tidak membuang-buang waktu dan biaya yang banyak dalam mengatasi permasalahannya. Melihat dari beberapa indicator kejahatan penulis beramsumsi bahwa hubungan lineart dengan efektifnya sanksi dan kepatuhan oleh tingkah laku. Oleh sebab itu perlu didalam penegakan hukum itu sendiri.

Hukum pidana ialah bagian dari keseluruhan hukum yang diberlakukan didalam sebuah negara. Hukum pidana terdiri dari beberapa norma yang berisikan keharusan dan larangan yang telah direkatkan dengan suatu sanksi berupa hukuman, adalah sebuah penderitaan yang sifatnya khusus. ${ }^{4}$ Oleh karena itu bisa juga dikatakan bahwa hukum pidana merupakan sebuah system norma yang menentukan tindakan-tindakan melakukan sesuatu atau tidak melakukan dimana terdapat sebuah keharusan untuk melakukan sesuatu dalam keadaan bagaimana hukuman itu dapat dijatuhkan sertah hukuman bagaimana yang dijatuhkan kepada tindakan tersebut. ${ }^{5}$

Menurut Undang-Undang Nomor 35 Tahun 2009 tentang Narkotika, yang dimaksudkan dengan narkotika itu ialah zat-zat atau obat-obatan terlarang yang asalnya dari tanaman atau tidak tanaman, baik tanaman sintetis maupun semi sinetetis yang bisa memberikan efek penurunan dan kehilangan kesadaran, hilang rasa, berkurangnya rasa myeri dan bisa menimbulkan efek ketergantungan atau kecanduan. Pada umumnya banyak orang yang tidak tahu narkotika karena benda tersebut didalam penyebutannya di media cetak atau media masa sudah terlalu sering dikatakan dengan sebutan narkoba. Meski yang mereka tahu beberapa macam dari narkotika itu, seperti ganja, shabu-shabu, heroin, kokain dan lain-lain. Narkotika tidak saja bias membuat penggunanya menjadi kecanduan, akan tetapi dapat juga mengakibatkan penggunanya meninggal secara cepat dan tidak wajar. ${ }^{6}$

\section{Rumusan Masalah}

1. Bagaimana pemidanaan terhadap pengguna sekaligus pengedar narkotika dalam praktik di Pengadilan Negeri Yogyakarta?

2. Bagaimanakah pertimbangan hakim dalam menjatuhkan sanksi pidana terhadap pengguna sekaligus pengedar narkotika di Pengadilan Negeri Yogyakarta?

\section{Metode Penelitian}

\section{Jenis Penelitian}

Penelitian ini menggunakan penelitian normatif yang merupakan penelitian hukum teoritis/dogmatik karena tidak mengkaji pelaksanaan atau implementasi hukum. Pokok kajian dalam penelitian normatif adalah hukum yang dikonsepkan sebagai norma atau kaidah yang belaku dalam masyarakat dan menjadi acuan perilaku setiap orang. Sehingga penelitian hukum normatif berfokus pada inventarisasi hukum positif, asas-asas dan doktrin hukum, penemuan hukum dalam perkara in concreto, sistematik hukum, taraf sinkronisasi, perbandingan hukum dan sejarah hukum. ${ }^{7}$

Berdasarkan penjelasan di atas, penulis memutuskan menggunakan metode penelitian hukum normatif untuk meneliti dan menulis pembahasan skripsi ini sebagai metode penelitian

4 Pemerintah Kota Yogyakarta, Perbedaan Pokok Hukum Pidana dan Hukum Perdata, https://hukum.jogjakota.go.id/articles/read/141, diakses pada tanggal 21 Januari 2020 Pukul 11.05.

5 M. Arief Hakim, Bahaya Narkoba-Alkohol: Cara Islam Mencegah, Mengatasi, dan Melawan, Bandung, Nuansa, 2004, hlm. 31.

6 Anton Santoso, "penerapan hukum pidana di Indonesia", Jurnal Hukum, 2012,Volume 7 Nomor 1

7 Abdulkadir Muhammad, Hukum dan Penelitian Hukum, Bandung, PT. Citra Aditya Bakti, 2004, hlm.52. 
hukum. Penggunaan metode penelitian normatif dalam upaya penelitian dan penulisan naskah ini dilatari kesesuaian teori dengan metode penelitian yang dibutuhkan penulis.

\section{Bahan Hukum}

Bahan hukum yang digunakan penulis di dalam penelitian ini yaitu data sekunder adalah data yang didapat dari hasil kajian-kajian pustaka, buku-buku, peraturan perundang-undangan, yurisprudensi, dan arsip ataupun data serta bahan hukum, dan juga peraturan hukum yang berkaitan dengan masalah yang diteliti penulis. ${ }^{8}$ Adapun bahan hukum sebagai berikut:

\section{a. Bahan Hukum Primer}

Bahan hukum primer yang digunakan dalam penelitian ini, yaitu bahan hukum yang terdiri dari peraturan perundang-undangan di bidang hukum yang mengikat, antara lain: ${ }^{9}$

1) Kitab Undang-Undang Hukum Pidana.

2) Undang-Undang Nomor 8 Tahun 1981 Tentang Hukum Acara Pidana.

3) Undang-Undang Nomor 5 Tahun 2009 tentang Narkotika.

4) SEMA (Surat Edaran Mahkamah Agung) Nomor 4 Tahun 2010 tentang Penempatran penyalahguna, Korban, dan Pecandu Narkotika ke dalam Lembaga Rehabilitasi Medis dan Rehabilitasi Sosial.

5) Peraturan Presiden Nomor 23 Tahun 2010 tentang Badan Narkotika Nasional (BNN).

b. Bahan Hukum Sekunder

Bahan hukum sekunder ini adalah bahan hukum yang memberi penjelasan mengenai bahan hukum primer, yaitu: 10

1) Buku-Buku Ilmiah.

2) Jurnal Hukum.

3) Putusan Nomor 357/Pid.Sus/2017/PN Yk,

4) Putusan Nomor 366/Pid.Sus/2017/PN Yk.

5) Pendapat, doktrin dan kesaksian yang tertulis maupun yang tidak tertulis.

c. Bahan Hukum Tersier

Bahan hukum tersier di penelitian ini yaitu bahan hukum yang memberi penjelasan dan petunjuk kepada bahan hukum primier dan juga bahan hukum sekunder, iaitu ensiklopedia dan kamus hukum. ${ }^{11}$

\section{Narasumber}

Narasumber (informan) penelitian adalah seorang yang karena memiliki informasi (data) banyak mengenai objek yang sedang diteliti, dimintai informasi mengenai objek penelitian tersebut. Adapun narasumber dalam penelitian ini adalah Ibu Tri Riswanti. SH., M. Hum selaku Hakim di Pengadilan Negeri Yogyakarta.

\section{Teknik Pengambilan Data}

Untuk mendapatkan data-data yang sesuai dengan permasalahan yang sedang diteliti penulis, oleh karena itu didalam penelitian ini penulis menggunakan teknik pengumpulan datadata sebagai berikut :

a. Wawancara

Dilakukan penulis dengan melakukan tanya jawab secara langsung mengenai masalah yang diteliti antara sumber-sumber yang berkaitan dengan obyek yang diteliti penulis.

b. Studi Kepustakaan dan Literatur

8 Mukti Fajar dan Yulianto Achmad, Dualisme Penelitian Hukum-Normatif dan Empiris, Yogyakarta, Pustaka Pelajar, 2015, hlm. 34

$9 \quad$ Ibid, hlm. 74

$10 \quad$ Ibid, hlm. 156

11 Ibid. 
Dengan mengkaji literature, peraturan perundang-undangan dan mempelajari dan juga sumber tertulis lainnya guna mendapatkan data yang berkaitan dan berhubungan dengan penelitian yang dilakukan penulis.

\section{Teknik Analisis Data}

Dalam penelitian ini, penulis menganalisa data dan menggunakan metode analisis kualitatif. Soerjono Sokanto mengatakan, analisis kualitatif ialah sebuah cara penelitian yang menghasilkan data deskriptif analisis yaitu apa yang dinyatakan oleh responden secara tertulis dan lisan serta perilaku yang nyata diteliti sebagai sebuah yang utuh. ${ }^{12}$

Analisa data kualitatif ini sebagai cara penyampaian berdasarkan hasil temuan dilapangan dan study kepustakaan, setelah itu disusun dan dilakukan pengolahan data hingga menghasilkan sebuah data yang kemudian dari data itu diambil beberapa kesimpulan. Dan juga perundangundangan yang mengatur tentang pemidanaan kepada pengguna sekaligus pengedar narkotika didalam Undang-Undang Nomor 35 Tahun 2009 tentang Narkotika.

\section{Hasil Penelitian dan Analisis}

\section{Pemidanaan Terhadap Pengguna Sekaligus Pengedar Narkotika}

Tindak pidana narkotika berdasarkan Undang-Undang nomor 35 tahun 2009, memberikan sanksi pidana cukup berat, disamping dapat dikenakan hukuman badan dan juga dikenakan pidana denda, tapi dalam kenyataannya para pelakunya semakin meningkat. Hal ini disebabkan oleh faktor penjatuhan sanksi pidana tidak memberikan efek terhadap para pelakunya. Sanksi pidana didalam UU Narkotika yang tertinggi yaitu hukuman mati. Ini diatur didalam Pasal 114 ayat (2), yaitu; "Dalam hal perbuatan yang menawarkan untuk dijual, menjual, membeli, atau membeli dalam satu harga, menukar, menyerahkan atau menerima Narkotika golongan 1 atau 1 untuk $1 \mathrm{~kg}$ atau melebihi 5 batang pohon atau dalam bentuk bukan tanaman beratnya 5 gram pelaku dipidana dengan penjara mati". Kepada pengedar narkotika layak dipidana mati. Berdasarkan pasal-pasal 114, 115, 118, 119. Dapat digunakan dengan kategori berat tindak kejahatan yang dibuat pelaku. Tindak pidana Narkotika ini telah memasuki setiap celah-celah kehidupan masyarakat, oleh karena itu, hukuman mati dilihat sangat harus diberlakukan di Negeri ini. Putusan MKRI (Mahkamah Konstitusi Republik Indonesia) menyebut bahwa sanksi pidana mati didalam UU Narkotika tidaklah bertentangan dengan Hak Asasi Manusia (HAM) yeng sudah di setujui oleh Undang-Undang Dasar Negara Tahun 1945.

Putusan Mahkamah Konstitusi Pabean yang digunakan untuk orang-orang yang melakukan kejahatan hukum tidak, karena ada sebagai (hak yang dapat didebit) sebagai hak seseorang yang dibatasi, akan tetapi sudah menjadi hak-hak yang telah disebutkan Hak Asasi Manusia (HAM) lain, yang memeberi pengaruh kepada hancurnya kaum milenial atau generasi muda dimasa yang akan datang. Hukuman mati sudah ditetapkandidalam pasal 10 Kitab UndangUndang Hukum Pidanayang termasuk dari bagian system Hukum Nasional. Penerapan hukuman mati tak bertentangan dengan Undang-Undang Dasar 1945. Dalam upaya menafsirkan UUD 1945 tentu tidak boleh dari satu sisi saja, harus memperhatikan semua yang berkaitan, didalam Pasal 28 a ayat (2), yakni didalam menjalankan hak dan juga kebebasan, setiap orang wajib tunduk pada pembatasan yang diterapkan dengan UU yang dimaksud hanya agar bias menjamin pengakuan dan penghormatan atas hak dan kebebasan orang dan guna memenuhi tuntutan yang seadil-adilnya dan pertimbangan moral, keamanan dan ketertiban umum dan juga nilai-nilai agama didalam kehidupan social masyarakat demokrasi. Namun pelaksanaanya haruslah hatihati dan selektif. Didalam pemberian hukuman mati, para majelis hakim juga mempunyai kebebasan besar yang dijamin didalam UU No 48 thn 2009 tentang Kekuasaan Kehakiman. Didalam Pasal 1 butir 1 UU No 48 thn 2009, Kekuasaan Kehakiman ialah kekuatan Negara yang Merdeka guna menyelenggarakan peradilan untuk penegakan hukum dan menegakkan Pancasila dan UUD RI.

12 Soerjono Soekanto, Pengantar Penelitian Hukum, Jakarta, UI Press, 1986, hal.52 
Hakim diberikan kewenangan untuk menentukan dan menjatuhkan pidana penjara atau tindakan rehabilitasi terhadap pengguna narkotika, namun disisi lain jelas bahwa pengedar narkotika harus dihukum dengan seberat-beratnya, guna mengetahui didalam kasus pengguna sekaligus pengedar narkotika, apakah hakim akan terapkan ketentuan pasal 114 dan pasal 127 yang mengatur tentang sanksi pidana atau memberlakukan ketentuan pasal 103 yang mengatur tentang Rehabilitasi, tentu akhirnya semua kembali kepada keyakinan hakim sendiri mengingat bahwa pasal 54 Undang-Undang nomor 35 tahun 2009 menyebutkan bahwa hanya Pengguna Narkotika dan korban penyalahgunaan saja yang wajib menjalani Rehabilitasi.

Penjatuhan Sanksi pidana terhadap pengguna sekaligus pengedar tindak pidana narkotika, menurut Tri Riswati sebagai Hakim Pengadilan Negeri Yogyakarta, menurutnya, "memang dia sebagai pengguna, tetapi dia juga sebagai pengedar, susunan atau bentuk dakwaan yaitu ancaman tertinggi, dia harus dijatuhkan hukuman sebagai pengedar, sesuai dengan teori dalam artian bagaimana dakwaan bagaimana pembuktiannya. Kalau dalam dakwaannya bukan sebagai pengedar, seperti dalam Pasal 112 117, dia menguasai, itupun masih menjadi pertimbangan majelis masing-masing istilahnya memang faktanya bagaiman dan teori yang dianut. Pada intinya bahwa untuk Pasal 112 jadi dia menguasai dan penguasaanya memang dalam rangka itu fakta persidangan kalau memang arahnya untuk dijual akan dikenakan Pasal 112, tetapi jika penguasaanya untuk digunakan sendiri itu juga ada batasannya yaitu ganja 5 gram, sabu-sabu 0,5 gram, itu dikeluarkan oleh Mahkamah Agung, jika terbukti sebagai pengguna dan pengedar bisa dikenakan sanksi pidana komulatif, namun disini hakim biasanya jarang melakukan hukuman pidana komulatif, dan akan di jatuhi hukuman sebagai pengedar, mungkin saja dia dijatuhi hukuman sebagai pengguna dan dapat dilakukan rehabilitasi, tapi dalam praktek selama ini di pengadilan negeri jogja rata-rata itu subsidairitas. Memang ada peraturan yang dinamakan peraturan bersama". ${ }^{13}$

Dari wawancara di atas, penulis menguraikan apa yang disebut sebagai peraturan bersama, yaitu peraturan Nomer 3 Tahun 2014 tentang Penanganan Pengguna Narkotika dan Korban Penyalahgunaan Narkotika ke dalam Lembaga Rehabilitasi, khsus untuk pengguna sekaligus pengedar.

\section{Pasal 5 :}

1. Pengguna dan korban penyalahguna narkotika sebagai tersangka dan terdakwa yang merangkap sebagai pengedar narkotika, ditahan di Rumah Tahanan Negara dan bagi yang bersangkutan bias memperoleh Rehabilitasi Medis dan Rehabilitasi Sosial yang dilaksanakan di Rumah Tahanan Negara atau Lembaga Pemasyarakatan (LP).

2. Selama proses penyidikan dan/atau penuntutan perkara berjalan, Penyidik dan/atau Jaksa Penuntut Umum melakukan koordinasi dengan pihak lembaga rehabilitasi dalam hal proses pengiriman dan penjemputan tersangka atau terdakwa dalam Tindak Pidana Narkotika.

\section{Pasal 6:}

1. Terdakwa atau Terpidana Pecandu Narkotika atau Korban Penyalahguna Narkotika yang sudah mendapatkan penetapan atau Putusan Pengadilan yang mempunyai kekuatan hukum tetap guna menjalani pengobatan dan perawatan melalui Rehabilitasi diserahkan oleh pihak Kejaksaan ke Lembaga Rehabilitasi Medis atau Rehabilitasi Sosial yang ditentukan.

2. Penyerahan sebagaimana yang di maksud pada ayat 1 diatas, dilakukan prosedur dan sesuai dengan ketentuan peraturan perUndang-Undangan yang berlaku.

\section{Pasal 7:}

1. Bagi Narapidan yang termasuk didalam kategori Pecandu Narkotika dan Korban Penyalahguna Narkotika, dan bukan pengedar atau bandar atau kurir atau produsen bias dilakukan Rehabilitasi Medis dan atau Rehabilitasi Sosial yang dilaksanakan didalam Lapas atau Rutan dan atau Lembaga Rehabilitasi yang telah ditentukan oleh Pemerintah.

13 Wawancara bersama Ibu Tri Riswati Hakim Pengadilan Negeri Yogyakarta, Kamis, 19 Juli 2018, Pukul 08.00 WIB 
2. Bagi Narapidana yang termasuk didalam kategori Pecandu Narkotika yang punya fungsi ganda sebagai Pengedar bias dilakukan Rehabilitasi Medis dana tau Rehabilitasi Sosial didalam Lapas atau Rutan.

3. Pelaksanaan Rehabilitasi Medis atau Rehabilitasi Sosial sebagaimana yang di dimaksud pada ayat 1 san ayat 2, dilakukan berdasarkan hasil assesmen dari Tim Assesmen Terpadu dan sesuai dengan ketentuan peraturan perundang-undangan yang berlaku.

Penjelasan diatas menunjukan bahwa Pengguna narkotika bisa mendapatkan tindakan rehabilitasi tetapi tidak semua bisa mendapatkannya, apalagi untuk pengguna yang merangkap menjadi pengedar semua tergantung berdasarkan hasil asesmen dari Tim Assessmen Terpadu dan sesuai dengan ketentuan peraturan perundang-undangan yang berlaku. Memahami efektif atau tidaknya penegakan hukum harus lah dipahami dengan baik, terlebih lagi tindak pidana narkotika, secara luas harusnya sudah dapat dimengerti dengan baik dan memahami maksud dari hukum tersebut. Norma Hukum ialah, "pokok aturan dari segala bentuk perundangundangan yang mengatur sangkut paut perhubungan anggota masyarakat dengan anggota masyarakat lainnya dalam kehidupan bermasyarakat". Oleh karena itu Norma Hukum ini ialah mengawasi seluruh kegiatan masyarakat didalam kehidupan, baik itu untuk diri sendiri kelompok masyarakat, harta benda maupun keuarganya.

Semua pengguna sekaligus pengedar narkotika tidak di vonis rehabilitasi, ini artinya hal ini cukup baik diterapkan baik untuk penegakan hukum maupun untuk kebaikan sipelaku sendiri. Oleh karena itu terdakwa kasus Pengguna sekaligus pengedar narkotika bisa mendapatkan rehabilitasi didalam penjara. Ada beberapa pengguna yang mendapatkan rehabilitasi tetapi hanya untuk diri sendiri. Begitu juga dengan pengguna, tidak semua juga mendapatkan rehabilitasi, semua kembali kepada putusan hakim. Kasus diataas juga memperlihatkan bahwa meningkatnya kasus penggunaan narkotika di Yogyakarta.

Tri Riswati selaku hakim di Pengadilan Negeri Yogyakarta menyatakan bahwa pengguna sekaligus pengedar narkotia ini adalah orang yang melawan hukum, karena itu hakim tidak menjatuhkan vonis rehanilitasi dan tindakan assesment Pengadilan Negeri Yogyakarta, karena untuk menekan tindakan yangtidak diinginkan sewaktu rehabilitasi. Mengenai rehabilitasi hakim juga harus melihat Surat Edaran Mahkamah Konstitusi (SEMA), yakni ada beberapa kriteria yang harus di haruskan mendapatkan rehabilitasi. Data yang penulis sematkan diatas yaitu data para pengguna sekaligus pengedar narkotika di Pengadilan Negeri Yogyakarta, bahwa semuanya telah di vonis penjara dan sesuai dengan SEMA tersebut.

Penjelasan mengenai tindakan yang dapat dikenakan bagi seorang pengguna Narkotika yang di maksud didalam pasal 127 jo pasal 54 jo pasal 103 Undang-Undang Nomor 35 Tahun 2009 tentang Narkotika, ialah SEMA RI (Surat Edaran Mahkamah Agung Republik Indonesia) Nomor 4 Tahun 2010 jo SEMA RI No 7 Tahun 2009, menjelaskan pecandu narkotika bisa di tempatkan didalam Lembaga Rehabilitasi, kriterianya adalah:

1. Pada saat terdakwa ditangkap Penyidik BNN atau Penyidik Kepolisian didalam kondisi tangkap tangan.

2. Disaat tertangkap tangan sesuai dengan butir a diatas, ditemukan barang bukti penggunaan 1 hari dengan perincian antara lain ebagai berikut:

a. Kelompok Metaphetamin (shabu-Shabu) seberat 1 gram.

b. Kelompok MDMA (Ektasi) seberat 2,4 gram atau sebanyak 8 butir.

c. Kelompok Heroin seberat 1,8 gram.

d. Kelompok Kokain seberat 1,8 gram.

e. Kelompok Ganja seberat 5 gram.

f. Daun Koka seberat 5 gram.

g. Meskalin seberat 5 gram.

h. Kelompok Psilosibin seberat 3 gram.

i. Kelompok LSD (D-Lusergic Acid Diethilamide) seberat 2 gram.

j. Kelompok PCP (Phencyclidine) seberat 3 gram. 
k. Kelompok Fentanil seberat 1 gram.

l. Kelompok Metadon seberat 0,5 gram.

m. Kelompok Morfin seberat 1,8 gram.

n. Kelompok Petidine seberat 0,96 gram.

o. Kelompok Kodein seberat 72 gram.

p. Kelompok Bufrenorfin seberat 32 gram.

3. Surat Uji Laboratorium yang berisikan Positive menggunakan Narkotika yang di keluarkan Penyidik.

4. Surat keterangan dari dokter jiwa atau psikiater Pemerintah yang diyunjuk Hakim.

5. Tidak terbukti bahwa yang bersangkutan terlibat didalam peredaran illegal Narkotika. ${ }^{14}$

Ketetapan di atas merupakan ketentuan untuk pengguna narkotika, yang mendapatkan atau dilakukan tindakan rehabilitasi, sekalugus untuk pengguna sekaligus pengedar narkotika, tentu saja semua kembali kepada hakim, apakah pasal yang digunakan pasal 114 atau bahkan 124 UU No. 39 Thn 2009 tentang Narkotika. Semua kembali didalam keyakinan hakim itu sendiri.

Penulis mencoba melihat beberapa kasus yang di tangani Pengadilan Negeri Yogyakarta yang kasus tersebut telah BAP. Yaitu putusan Nomor 316/Pid.Sus/2016PN.Yyk.

\section{1) Putusan Nomor 316/Pid.Sus/2016PN}

\section{a. Kasus Posisi}

Bahwa terdakwa Muhammad Bayu bin Sumarto, pada hari sabtu tanggal 20 agustus 2016 sekitar jam 13.00 wib atau setidaknya pada suatu waktu dalam bulan agustus 2016, berlokasi dihalaman parker Circle K di jalan Jendral Sudirman Kel. Terban Kec. Gondokusuman Kota Yogyakarta atau setidaknya disuatu tempat yang termasuk dalam daerah hukum Pengadilan Negeri Yogyakarta, telah tanpa haka tau melawan hukum, menjual, membeli, memiliki menyimpan, menguasai atau menyediakan Narkotika Golongan I bukan tanaman, yang di lakukan terdakwa dengan cara berikut:

Bahwa awal mula petugas kepolisisan dari Polda DIY mendapat informasi dari masyarakat mengenai keterlibatan terdakwa yang diduga melakukan transaksi penyalahgunaan narkotika, untuk itu petugas kepolisian melakukan penyelididkan dan penyidikan terhadap terdakwa, maka petugas kepolisian dari Dit Narkoba Polda DIY pada hari sabtu tanggal 20 agustus 2016 sekitar pukul 13.00 wib melakukan penangkapan dan penggeledahan terhadap terdakwa.

Bahwa dari hasil penggeledahan yang dilakukan terhadap terdakwa, petugas mendapati 2 paket shabu yakni paket shabu siap edar dengan berat kotor 0,48 gram serta plastic klipnya ditemukan dilantai sepeda motor mio yang dipakai terdakwa. Bahwa barang bukti di sita dari terdakwa berupa 1 bungkusan amplop warna coklat muda di dalamnya terdapat 1 plastik klip berisi Kristal transparan di duga shabu dengan berat isi 0,29 gram (kode lab 02157/T/08/2016) dan 1 plastik klip berisi Kristal transparan di duga shabu (kode lab 020158/T/08/2016) semuanya positif mengandung Metamfetamin sepertim yang terdaftar didalam Golongan I nomor urut 61 lampiran Undang-Undang Ri Nomor 35 Tahun 2009 tentang Narkotika, sesuai dengan Berita Acara Pemeriksaan (BAP) Laboratorium Nomor : 440/2058/C.3 tanggal 27 Agustus 2016 dari Laboratorium Penguji Balai Laboratorium Kesehatan Yogyakarta yang di buat dan di tandatangani atas nama Kepala Balai Laboratorium Kesehatan Yogyakarta Drh. Betty Murtininghsih, M. Kes, Tim Pemeriksaan Manager Teknik Dr. Woro Umi Ratih, Sp PK, M Kes, serta penguji Chintya Yuli Astuti, S. Farm, Apt dan Karjiman, SST.

Perbuatan terdakwa sebagaimana di atur dan di ancam pidana dalam pasal 112 ayat (1) Undang-Undang RI Nomor 35 Tahun 2009 tentang Narkotika.

14 Ibid. 


\section{b. Pasal yang dilanggar}

1) Pasal 112 ayat 2 Undang-Undang Republik Indonesia Tahun 2009 tentang Narkotika.

\section{c. Putusan Pengadilan Negeri Yogyakarta Nomor: 357/Pid.Sus/2017/PN Yk}

1) Menyatakan Terdakwa Muhammad Bayu bin Sumarto telah terbukti secara sah dan meyakinkan bersalah melakukan tindak pidana menjual, memiliki, menyimpan dan menyediakan narkotika Golongan I bukan tanaman.

2) Menjatuhkan pidana terhadap Terdakwa tersebut penjara selama 4 (empat) Tahun dan denda sebesar Rp. 800.000.000 (Delapan Ratus Juta Rupiah), dengan ketentuan apabila denda tersebut tidak dibayarkan, maka diganti dengan penjara selama tiga bulan.

3) Menetapkan lamanya masa Penangkapan dan Penahanan dijalani Terdakwa dikurangi seluruhnya dari pidana yang dijatuhkan.

4) Menetapkan agar Terdakwa tetap ditahan.

5) Menyatakan barang bukti berupa:

a) 1 (satu buah plastic klip berisi sisa serbuk shabu berat 0,59 gram.

b) 1 buah plastic klip berisi serbuk Kristal shabu berat 0,48 gram.

c) 1 unit handphone Samsung warna hitam.

d) 1 buah topi warna hitam dengan tulisan "Enggak ada matinya".

e) 1 unit sepeda motor Yamaha mio warna merah atas nama Fajar Kumbara.

6) Dikembalikan kepada Sumartono (Ayah Terdakwa).

\section{d. Analisis Kasus}

Melihat Putusan diatas, Penulis mendapatkan bahwa Hakim memutuskan untuk menerapkan dakwaan alternatif pasal 112 ayat (1) UU No. 35 Thn 2009 tentang Narkotika dan UU No. 8 Thn 1981 tentang Hukum Acara Pidana (KUHAP). Keterangan tersebut berarti Terdakwa Muhammad Bayu bin Sumarto harus tetap ditahan sesuai vonis yang dijatuhkan. Terdakwa tidak mendapatkan hukuman rehabilitasi, karena melihat dari fakta persidangan, terdakwa dengan jelas melakukan perbuatan melawan hukum menjual, menggunakan atau menyimpan narkotika jenis sabu-sabu untuk digunakan dan diperjualbelikan.

\section{2) Putusan Nomor 366/Pid.Sus./2017PN. Yk}

\section{a. Kasus Posisi}

Bahwa Terdakwa MUHAMMAD RIFKI ROMADHON Bin BOB SOLOKANA Pada Hari Sabtu Tnggal 14 Oktober 2017 sekitar pukul 23.15 WIB atau Sekiranya disuatu waktu pada Bulan Oktober tahun 2017, di Kos Ibu SRI LESTARI dengan alamat Brajan RT.02, Kel. Tamantirto, Kec. Kasihan, Kab. Bantul, D.I.Yogyakarta. Bahwa terdakwa Muhammad Rifki Romadon, secara tanpa hak memiliki, menyimpan dan/atau membawa psikotropika. perbuatan Terdakwa tersebut di lakukan dengan cara sebagai berikut; Bahwa pada hari Sabtu Tanggal 14 Oktober 2017 siang hari petugas Kepolisian Resort Kota Yogyakarta yang terdiri dari saksi UNTORO, saksi HUDIHARJANA, saksi BRURI SABTONO NUGROHO dan saksi YUYUN HANDOKO mendapatkan informasi dari masyarakat bahwa ada penyalahgunaan Psikotropika Golongan IV disekitar alun - alun Selatan Kraton Yogyakarta.

Penyelidikan dilakukan untuk mendapatkan informasi bahwa pelaku penyalahgunaan Psikotropika Golongan IV tersebut tinggal di daerah Brajan, Tamantirto, Kasihan, Bantul. Kemudian sekira pukul 23.15 WIB, tim dari Kepolisian Resort Kota Yogyakarta yang terdiri dari saksi UNTORO, saksi HUDIHARJANA, saksi BRURI SABTONO NUGROHO dan saksi YUYUN HANDOKO melakukan penangkapan terhadap Terdakwa di Kos Ibu SRI LESTARI dengan alamat Brajan RT.02, Kel. Tamantirto, Kec. Kasihan, Kab. 
Bantul, D.I. Yogyakarta dan setelah dilakukan penggeledahan ditemukan barang bukti berupa: 1 (satu) buah kotak kardus berlakban warna coklat yang dibungkus plastik warna merah dari JNE beserta resi pengiriman yang didalamnya berisi 1 (satu) box Alprazolam 1 mg berisi 3 (tiga) bungkus plastik masing - masing berisi 10 (sepuluh) lembar dan setiap lebmarnya berisi 10 (sepuluh) butir Alprazolam $1 \mathrm{mg}$ dengan jumlah keseluruhan 300 (tiga ratus) butir Alprazolam 1 mg yang ditemukan dibelakang pintu kamar kos Terdakwa, 1 buah Handphone jenis/merk Blackberry warna putih dan 1 buah kartu ATM BCA yang diakui kepemilikannya oleh Terdakwa. Selanjutnya Terdakwa tidak mempunyai hak untuk memiliki, menyimpan dan/atau membawa psikotropika, oleh karenanya Terdakwa bersama dengan serta barang bukti yang ditemukan dibawa menuju ke Kantor Kepolisian Resort Kota Yogyakarta untuk pemeriksaan lebih lanjut.

\section{b. Pasal yang dilanggar}

1) Pasal 114 ayat (2) UU RI No 35 tahun 2009 tentang Narkotika.

2) Pasal 127 ayat (1) UU RI No 35 tahun 2009 tentang Narkotika.

3) Pasal 62 UU RI No 5 tahun 1997 tentang Psikotropika.

\section{c. Putusan Pengadilan Negeri Yogyakarta Nomor: 366/Pid.Sus./2017PN. Yk}

Menyatakan Terdakwa MUHAMMAD RIFKI ROMADHON sudah terbukti bersalah secara Sah dan meyakinkan melakukan perbuatan Tindak Pidana Narkotika, secara melawan hukum dan tanpa hak,membawa, menyimpan dan / atau memiliki psikotropika sebagaimana diatur dan diancam pidana dalam Undang-Undang R.I. Nomor 05 Tahun 1997 tentang Psikotropika. Menjatuhkan pidana terhadap Terdakwa MUHAMMAD RIFKI ROMADHON Bin BOB SOLOKANA dengan pidana penjara selama 2 tahun (dikurangi selama Terdakwa berada dalam tahanan dengan Terdakwa tetap ditahan dan pidana denda sebesar Rp 5.000 .000 subsidiair 2 (dua) bulan.

\section{d. Analisis Kasus}

Kasus tersebut jelas bahwa melanggar pasal 62 UU No 5 tahun 1997 tentang psikotropika. Bahwa terdakwa secara jelas memesan dan membeli secara online, dalam putusan ini tentu hakim mempertimbangkan sesuai dengan dakwaan dan Undang-Undang Narkotika. Bahwa jenis narkotika yang berbentuk pil tersebut masuk kedalam kategori IV. berdasarkan Berita Acara Laboratorium Pengujian Dan Kalibrasi Laboratorium Kesehatan Yogyakarta No:441/03212/C.3 tanggal 27 Oktober 2017 yang pada pokoknya menyimpulkan bahwa BB-77.e/X/2017SatResNarkoba mengandung ALPRAZOLAM termasuk didalam golongan IV nomor urut 2 Lampiran Undang-Undang Republik Indonesia No. 5 Tahun 1997 tentang Psikotropika dan berdasarkan Surat Hasil Pemeriksaan Urine Nomor R/327/X/2017/Bidokkes Kepolisian Daerah Istimewa Yogyakarta tanggal 15 Oktober 2017, pada pokoknya menyimpulkan bahwa hasil pemeriksaan urine atas nama MUHAMMAD RIFKI ROMADHON Bin BOB SOLOKANA menunjukkan BENZODIAZEPINES POSITIF mengandung ALPRAZOLAM.

Bahwa didalam hukum, pemidanaan terhadap pengguna sekaligus pengedar narkotika, dakwaan yang diajukan Jaksa Penuntut Umum adalah alternative. Oleh karena itu, pengadilan didalam menjatuhkan pidananya, hanya menjatuhkan pidana yang terbukti di pengadilan sesuai dengan perbuatan terdakwa.

\section{Pertimbangan Hakim dalam Pemidanaan terhadap Pengguna sekaligus Pengedar Tindak Pidana Narkotika}

Pertimbangan Hakim adalah pemikiran-pemikiran atau pendapat hakim dalam menjatuhkan putusan dengan melihat hal-hal yang dapat meringankan atau memberatkan 
pelaku. ${ }^{15}$ Suatu putusan yang dibuat oleh hakim ialah akhir dari sebuah kasus/perkara yang tengah diadili didalam persidangan. Maka tentunya dalam hal terkait putusan hakim harus perhatikan segala sesuatu untuk dipertimbangkan, butuh kejelian dan hati-hati, menghindari segala yang tidak cermat yang bersifat Formil ataupun Materil, sampai pada akhirnya telah cakap membuat putusan. Bilamana hal negatif bisa dihindari, tentunya didalam diri hakim, tumbuh lahir dan berkembang nya sifat dan sikap adil dan puas secara moral, apalagi bila dikemudian hari outusan tersebut bisa dijadikan tuntunan untuk kasus/perkara yang serupa, atau bahkan bisa jadi bahan Refrensi oleh kaum teoritis ataupun kaum praktisi hukum, dan juga tentu kepuasan nurani sendiri bila putusan tersebut diperkuat dan tidak di batalkan Pengadilan yang lebih tinggi.

Pertimbangan fakta dan keadaan yang didapat dari pemeriksaan didalam persidangan adalah dasar dari menentukan kesalahan si terdakwa, setelah itu barulah hakim mempertimbangkan factor yang dapat meringankan atau memberatkan pidana. ${ }^{16}$ Memperhatikan juga bahwa semua unsur pidananya telah terpenuhi didalam rumusan kejahatan pidana beserta kualifikasi sebagaimana yang ditentukan didalam pasal 197 huruf d Kitab Undang-Undang Hukum Pidana. Seperti ketetntuan diatas, hakim juga mempertimbangkan faktor yang bisa meringankan atau memberatkan untuk terdakwa seperti ketentuan diatas tersebut, oleh karena itu penjatuhan pidana oleh hakim di harapkan sudah sesuai dengan kesalahan terdakwa dan perbuatannya, tata tertib hukum tentu haruslah dipertahankan. Maka usaha pemidanaan yang di lakukan bukan semata mata berdasarkan guna maksud pembalasan, justeru didalamnya mengandung tujuan khusus mencapai suatu yang positif, seperti melindungi masyarakat dan mencegah dari tindak pidana narkotika.

Didalam pasal 27 UU No. 48 Thn 2009 tentang Pokok-Pokok Kekuasaan Kehakiman, faktor mempertimbangkan masalah yang menyangkut terdakwa, didapat 2 (dua) pengasan, yaitu:

1.Hakim selaku penegak hukum dan keadilan, wajib mengikuti, menggali dan memahami nilai hukum yang hidup didalam masyarakat.

2.Didalam mempertimbangkan ringan beratnya hukuman terdakwa, hakim juga wajib memperhatikan sifat sifat baik dan sifat buruk dari terdakwa.

Masalah lain didalam pertimbangan hakim dalam menjatuhkan pidana, yaitu pedoman pemidanaan. ${ }^{17}$ Pedoman ini adalah suatu yang begitu membantu para hakim didalam mempertimbangkan ringan beratnya hukuman pidana yang dijatuhkan terhadap siterdakwa. Pedoman tersebut memudahkan para hakim didalam menhatuhkan pidana. Muatan didalam pedoman pemidanaan ini berupa sebuah daftar yang perlu di teliti lebih dulu sebelum pidana dijatuhkan hakim, sehimgga di harapkan pidana yagn dijatuhkan terhadap siterdakwa bisa lebih pro-porsional dan bisa di pahami oleh masyarakat umum serta siterpidana sendiri. Oleh karena itu, pertimbangan hakim didalam menjatuhkan putusan adalah menyesuaikan dakwaan yang diajukan Penuntut Umum (PU), maka pertimbangan yang pertama hanya dakwaa yang telah terbukti tidak dua-duanya atau kumulatif.

\section{Simpulan dan Saran}

\section{Simpulan}

Berdasarkan dari hasil penelitian tentang pemidanaan terhadap pengguna sekaligus pengedar tindak pidana narkotika, penulis mendapatkan kesimpulan sebagai berikut :

15 Vina Amelia Aristantia, Analisis Pertimbangan Hukum Hakim Dalam Menjatuhkan Pidana Terhadap Anak Pengedar Uang Palsu (Studi Putusan Nomor: 13/Pid/Sus.Anak/2016/PN.Met), Bandar Lampung, Fakultas Hukum, Universitas Lampung, 2017,HIm. 26

16 Ibid, hlm. 21

17 Rara Kristi Aditya Mutiaramadani, Dasar Pertimbangan Hakim Dalam Menjatuhkan Sanksi Pidana Penjara Terhadap Anak Sebagai Pelaku Tindak Pidana Pencurian Dengan Teori Pemidanaan (Studi di Pengadilan Negeri Mojokerto), Malang, Fakultas Hukum, Universitas Brawijaya, 2013, hlm. 3 
a. Pemidanaan terhadap pengguna sekaligus pengedar narkotika adalah sesuai dengan ketentuan pasal 114 Undang-Undang Nomor 35 Tahun 2009 tentang Narkotika. Tersangka yang melakukan tindak pidana narkotika dikenakan sanksi sebagai pengedar, dimana sesuai dengan UU No 35 Tahun 2009. Keadaan seperti ini didasari oleh pertimbangan bahwa pengadilan harus melakukan sanksi yang berat bagi pelaku. Tindakan yang diterapkan harus mampu menekan atau mengurangi peredaran narkotika tersebut. Sesuai dengan pasal 114 bahwa pengguna dan pengedar telah terbukti di pengadilan akan diterapkan hukuman seberat beratnya. Bahkan hakim bias menerapkan hukuman mati kepada pelaku, tentu saja dengan melihat dakwaan atau seberapa besar kesalahan pelaku terhadap peredaran ini

b. Pertimbangan hakim didalam pemidanaan terhadap pengguna sekaligus pengedar Tindak Pidana Narkotika :

1) Dasar pertimbangan hakim dalam penjatuhan pidana terhadap Pengguna sekaligus pengedar tindak pidana narkotika di Pengadilan Negeri Yogyakarta, bahwa berdasarkan pertimbangan yuridis yaitu meihat dari peraturan perUndangUndangan, surat dakwaan, surat tuntutan oleh Jaksa Penuntut Umum, keterangan saksi dan keterangan terdakwa di dalam persidangan. Dan dasar pertimbangan non yuridis yaitu berdasarkan kebijaksanaan dan keyakinan hati nurani seorang hakim, dalam melihat keadaan yang di golongkan antara lain latar belakang perbuatan, kondisidiri, kondisi sosial ekonomi, sifat sopan dan santun terdakwa dalam persidangan. Selain itu hal-hal yang meringankan dan memberatkan juga masuk ke dalam dasar pertimbangan hakim yang bersifat non yuridis.

2) Masalah/kendala yang didapat oleh para hakim didalam penjatuhan sanksi pidana terhadap pengguna sekaligus pengedar tindak pidana narkotika antara lain, pertama kendala internal yaitu kendala proses selama di dalam persidangan penjatuhan pidana itu sendiri. Yang kedua kendala eksternal yaitu kendala yang berasal dari luar lingkup proses persidangan penjatuhan pidana.

3) Upaya yang dilakukan oleh hakim untuk mengatasi kendala dalam penjatuhan pidana terhadap pengguna sekalgus pengedar tindak pidana narkotika adalah dalam memberikan pertimbangan hukum seorang hakim harus memiliki keyakinan sendiri, hakim juga harus memilisi sifat kemandirian, dan dapat memperkuat dasar pertimbangan haakim, serta partisipasi masyarakat akan memberikan efek putusan yang adil dan seimbang menurut masyarakat.

\section{Saran}

Berdasarkan kesimpulan di atas pada akhir skripsi ini, penulis memberikan beberapa saran sebagai berikut :

a. Bagi aparat penegak hukum khususnya hakim, dalam menjatuhkan pidana terhadap tindak pidana penyalahgunaan narkotika yang dilakukan oleh anggota Kepolisian, seharusnya pada saat memberikan pertimbangan dapat lebih menganalisis dan menjatuhkan putusan terhadap pelaku secara benar dengan berlandaskan asas penegakan hukum yang berkeadilan.

b. Majelis hakim yang terhormat seharusnya lebih tegas lagi didalam hal penjatuhan atau penetapan hukuman/sanksi pidana kepada Pengguna sekaligus pengedar tindak pidana narkotika dan bilamana diperlukan menerapkan sanksi pidana paling tinggi atau Maksimal terhadap pelaku, maka dari itu para majelis hakim tidak perlu lagi ragu-ragu dalam menjatuhkan hukuman maksimal sesuai dengan fakta persidangan.

c. Bagi masyarakat, supaya dapat menjadi sarana bantu penegakan hukum dengan mengawasi jalannya peradilan, serta harus meningkatkan kembali rasa kepercayaan kepada negara. Semua hal itu agar dapat terciptanya putusan hakim yang mencerminkan kepastian hukum, berkeadilan dan berkemanfaatan bagi masyarakat, bangsa dan negara. 


\section{DAFTAR PUSTAKA}

\section{Buku}

Abdulkadir Muhammad, 2004, Hukum dan Penelitian Hukum, PT. Citra Aditya Bakti, Bandung, hlm.52.

M. Arief Hakim, 2004, Bahaya Narkoba-Alkohol: Cara Islam Mencegah, Mengatasi, dan Melawan. Bandung: Nuansa.

Soerjono Soekanto, 1986, Pengantar Penelitian Hukum, UI Press, Jakarta, hal.52.

Mukti Fajar, Yulianto Achmad, 2015, Dualisme Penelitian Hukum-Normatif dan Empiris, Yogyakarta, Pustaka Pelajar

\section{Jurnal}

Aktualita, 2018, "Menanggulangi Tindak Pidana Narkotika Dihubungkan Dengan Tujuan Pemidanaan," Jurnal Aktualita, Volume 1 Nomor 1.

Anton Santoso, 2012, “Penerapan Hukum Pidana Di Indonesia." Jurnal Hukum

Volume 7 Nomor 1

\section{Skripsi}

Vina Amelia Aristantia, 2017, ANALISIS PERTIMBANGAN HUKUM HAKIM DALAM MENJATUHKAN PIDANA TERHADAP ANAK PENGEDAR UANG PALSU (Studi Putusan Nomor: 13/Pid/Sus.Anak/2016/PN.Met), Fakultas Hukum, Universitas Lampung, Bandar Lampung.

Rara Kristi Aditya Mutiaramadani, 2013, Dasar Pertimbangan Hakim Dalam Menjatuhkan Sanksi Pidana Penjara Terhadap Anak Sebagai Pelaku Tindak Pidana Pencurian Dengan Teori Pemidanaan (Studi di Pengadilan Negeri Mojokerto), Fakultas Hukum, Universitas Brawijaya, Malang.

\section{Peraturan}

Kitab Undang-Undang Hukum Pidana

Undang-Undang Nomor 8 Tahun 1981 Tentang Hukum Acara Pidana.

Undang-Undang Nomor 5 Tahun 2009 tentang Narkotika. 